\title{
4-Aminopyridine affects synaptosomal protein phosphorylation in rat hippocampal slices
}

\author{
Pierre N.E. De Graan ${ }^{1}$, Loes H. Schrama ${ }^{1}$, Arjen B. Brussaard ${ }^{1}$, \\ Reinhard Jork ${ }^{2}$ and Willem Hendrik Gispen ${ }^{1}$ \\ 'Division of Molecular Neurobiology, Rudolf Magnus Institute for Pharmacology and Institute of Molecular Biology and \\ Medical Biotechnology, University of Utrecht, Utrecht (The Netherlands) and ${ }^{2}$ Institute of Pharmacology and Toxicology, \\ Medical Academy Magdeburg, Magdeburg (F.R.G.)
}

(Accepted 14 October 1986)

Key words: Protein phosphorylation; Hippocampal slice; 4-Aminopyridine; Epilepsy; $\mathrm{Ca}^{2+} / \mathrm{calmodulin}^{2}$

\begin{abstract}
Rat brain hippocampal slices were incubated with or without the convulsant 4-aminopyridine (4-AP). From these slices a crude mitochondrial/synaptosomal membrane fraction was prepared and analyzed for endogenous protein phosphorylation. $4-\mathrm{AP}\left(10^{-5} \mathrm{M}\right)$ stimulated the phosphorylation of a $50 \mathrm{kDa}$ protein by $86 \%$. The phosphorylation of this $50 \mathrm{kDa}$ protein is Ca ${ }^{2+} / \mathrm{calmodulin}^{-\mathrm{depen}-}$ dent and we suggest that this protein is the lower molecular weight subunit of $\mathrm{Ca}^{2+}$ /calmodulin-dependent protein kinase II (CaMK II).
\end{abstract}

The molecular mechanisms underlying epileptogenesis at the level of the neuronal membrane are largely unknown. One of the experimental models to study epileptogenesis is the 4-aminopyridine model of epilepsy. The convulsant drug, 4-aminopyridine (4-AP), is known to block potassium channels associated with an influx of calcium ${ }^{3,16,22,27}$. Several lines of evidence point to a crucial role of calcium in epileptogenesis and the action of convulsant drugs ${ }^{9}, 10,15,29,32 \cdot \mathrm{Ca}^{2+}$-dependent phosphorylation of membrane proteins may be one of the processes underlying changes in synaptic plasticity found in epileptogenesis ${ }^{8,33,34}$.

The transverse hippocampal slice system has been widely used to study the neural mechanisms underlying epileptogenesis and the related phenomenon of long-term potentiation (LTP). In this slice system, the degree of phosphorylation of several proteins has been reported to correlate with the degree of $\mathrm{LTP}^{6,23,26,28}$. This paper describes changes in the post hoc phosphorylation of proteins in a crude mitochondrial/synaptosomal fraction prepared from hippo- campal slices treated with 4-AP.

Hippocampal slices $(400 \mu \mathrm{m})$ were prepared from male inbred Wistar rats (TNO, Zeist, NL) ${ }^{28}$. The slices were incubated in $2 \mathrm{ml}$ Krebs-Ringer buffer (KRB): $124 \mathrm{mM} \mathrm{NaCl}, 5 \mathrm{mM} \mathrm{KCl}, 1.2 \mathrm{mM}$ $\mathrm{NaH}_{2} \mathrm{PO}_{4}, 1.3 \mathrm{mM} \mathrm{MgSO}_{4}, 26 \mathrm{mM} \mathrm{NaHCO}, 10 \mathrm{mM}$ glucose, $2 \mathrm{mM} \mathrm{CaCl}_{2}$, pH 7.4 equilibrated with $5 \%$ $\mathrm{CO}_{2} / 95 \% \mathrm{O}_{2}$ at $34{ }^{\circ} \mathrm{C}$. The slices were divided over glass tubes in such a way that each tube contained 3 slices from 3 different rats. After preincubation for $60 \mathrm{~min}$ at $34{ }^{\circ} \mathrm{C}$, the medium was replaced by $2 \mathrm{ml}$ KRB containing 4-AP (Sigma, St. Louis, MO, U.S.A.) at the concentrations indicated or by KRB alone. Incubation with or without the convulsant was continued for $30 \mathrm{~min}$ and the incubation was then stopped by replacing the medium with $3 \mathrm{ml}$ ice-cold $0.32 \mathrm{M}$ sucrose. Immediately after this washing step the 3 slices were homogenized in $300 \mu \mathrm{l} 0.32 \mathrm{M}$ sucrose in a Potter-Elvehjem tube with a Teflon pestle (7 strokes at $1400 \mathrm{rpm}$, clearance $0.250 \mathrm{~mm}$ ). The homogenate was centrifuged for $10 \mathrm{~min}$ at $1000 \mathrm{~g}$ and the resulting supernatant was centrifuged at $10,000 \mathrm{~g}$

Correspondence: P.N.E. De Graan, Division of Molecular Neurobiology, Institute of Molecular Biology and Medical Biotechnology, University of Utrecht, Padualaan $8,3584 \mathrm{CH}$ Utrecht, The Netherlands. 
for $20 \mathrm{~min}$ to obtain a crude mitochondrial/synaptosomal fraction $\left(\mathrm{P}_{2}\right)$. The $\mathrm{P}_{2}$ obtained from three slices was lysed in $120 \mu \mathrm{l}$ ice-cold $\mathrm{H}_{2} \mathrm{O}$ for $15 \mathrm{~min}$ and the ion concentration was adjusted to $10 \mathrm{mM}$ sodium acetate, $10 \mathrm{mM}$ magnesium-acetate, $0.1 \mathrm{mM}$ calcium acetate ( $\mathrm{pH} 6.5$, buffer $\mathrm{A}$ ) with a 10 times concentrated solution.

The phosphorylation assay was performed according to Zwiers et al. ${ }^{36}$ as modified by Kristjansson et al. ${ }^{13}$, with $10 \mu \mathrm{g}$ protein (determined according to Lowry et al. ${ }^{18}$ ), $7.5 \mu \mathrm{M}$ ATP, $2 \mu \mathrm{Ci}\left[\gamma_{-}{ }^{32} \mathrm{P}\right] \mathrm{ATP}$ (New England Nuclear, Boston, USA, spec. act. 3000 $\left.\mathrm{Ci} \cdot \mathrm{mmol}^{-1}\right)$ in buffer $\mathrm{A}$ for $15 \mathrm{~s}$ at $30^{\circ} \mathrm{C}$ in $25 \mu \mathrm{l}$. The reaction was terminated by addition of $12.5 \mu \mathrm{l}$ denaturating solution ${ }^{36}$. The proteins were separated on $11 \%$ slab gels ${ }^{36}$ at $30 \mathrm{~mA}$ and the front was run of the bottom of the gel for $30 \mathrm{~min}$ in order to improve the separation of the phosphoproteins in the $50 \mathrm{kDa}$ range. The incorporation of phosphate into proteins was quantified by scanning of the autoradiogram ac-

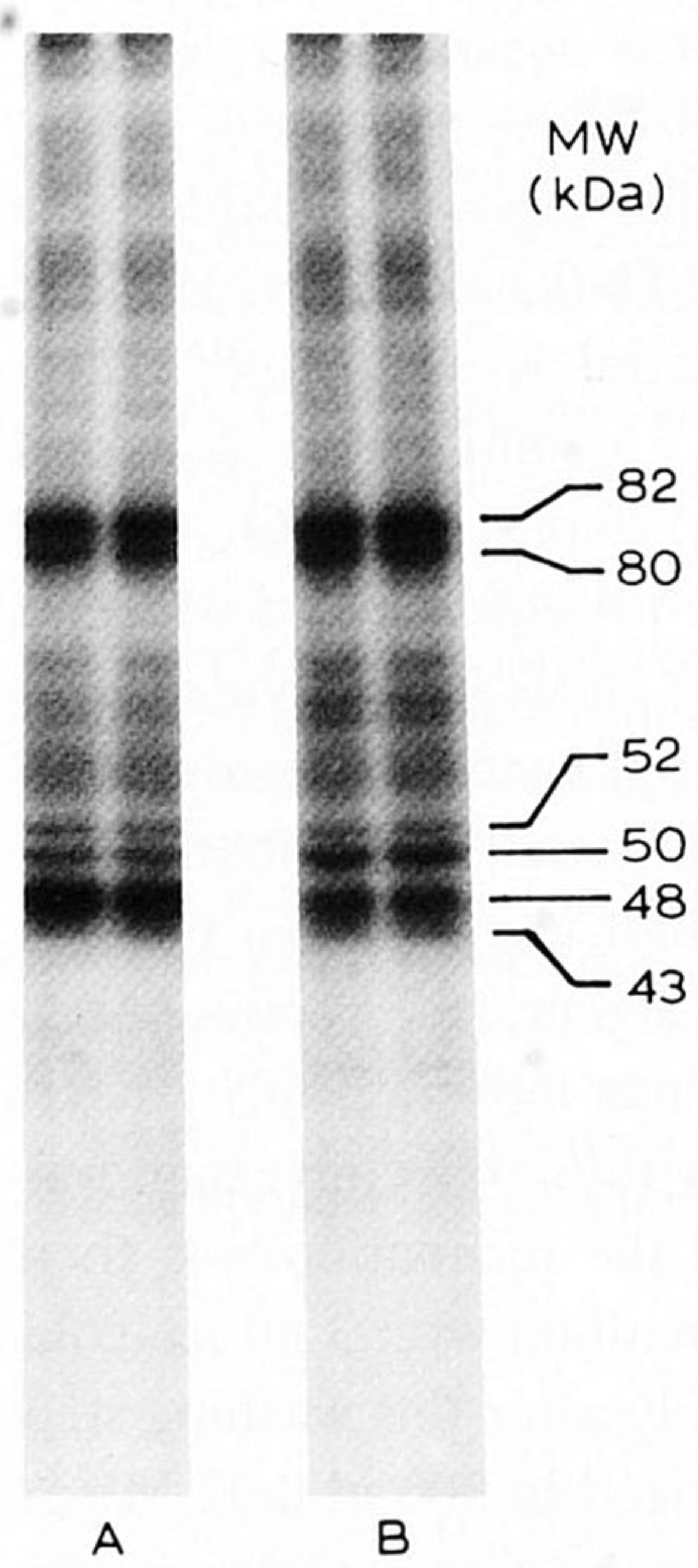

Fig. 1. Autoradiogram showing the effect of 4-AP treatment of hippocampal slices on in vitro endogenous protein phosphorylation. Slices were incubated without (A) or with (B) $10^{-5} \mathrm{M}$ 4AP for $30 \mathrm{~min}$. From these slices a crude mitochondrial/synaptosomal $\left(\mathrm{P}_{2}\right)$ fraction was prepared and phosphorylated with $[\gamma-$ $\left.{ }^{32} \mathrm{P}\right]$ ATP. Proteins were separated by $11 \%$ SDS-PAGE and subjected to autoradiography. Estimated molecular weights of the 6 major phosphoproteins are indicated. cording to Zwiers et al. ${ }^{36}$ and expressed as peak height above background. Comparisons between experimental and control groups were only made per one gel and the results are expressed as percentage difference to control (100\%). Statistical analysis was performed using Student's $t$-test.

The major phosphoproteins present in the crude mitochondrial/synaptosomal fraction are shown in Fig. 1 and have been designated on the right side of the figure according to their relative molecular weights. The most pronounced effect of incubation of slices with $10^{-5} \mathrm{M} 4$-AP is a stimulation of the phosphorylation of a $50 \mathrm{kDa}$ protein. Quantification of the autoradiogram shown in Fig. 1 revealed that this stimulation of $50 \mathrm{kDa}$ phosphorylation was $86 \%$ over control (Fig. 2). In addition there was a small yet significant stimulation of $80 \mathrm{kDa}$ phosphorylation. The 4-AP-induced stimulation of $50 \mathrm{kDa}$ phosphorylation was dose-dependent (Fig. 3) and was detectable at concentrations as low as $10^{-7} \mathrm{M}$. The effect of 4-AP

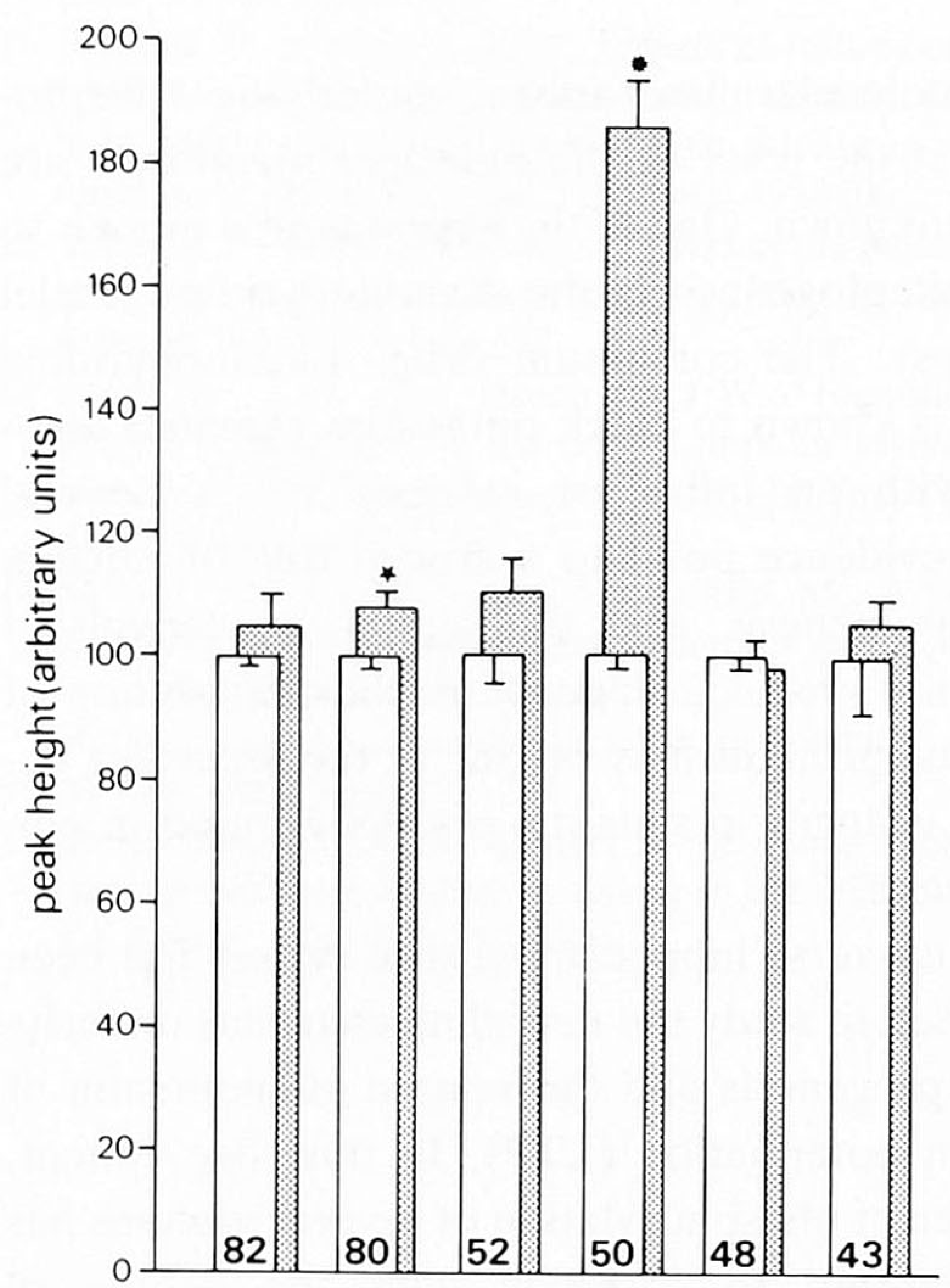

Fig. 2. Quantification of the effect of $10^{-5} \mathrm{M} 4$-AP as shown on the autoradiogram in Fig. $1(n=13)$. Quantification was performed by densitometric scanning of the autoradiogram and expressed as peak height above background. The data are expressed as percentage relative to control $(100 \%)$. Indicated are: the mean and standard error of the mean (S.E.M., bars). $\star, 2 P<0.05,{ }^{*}, 2 P<0.001$, as determined with Student's t-test. 

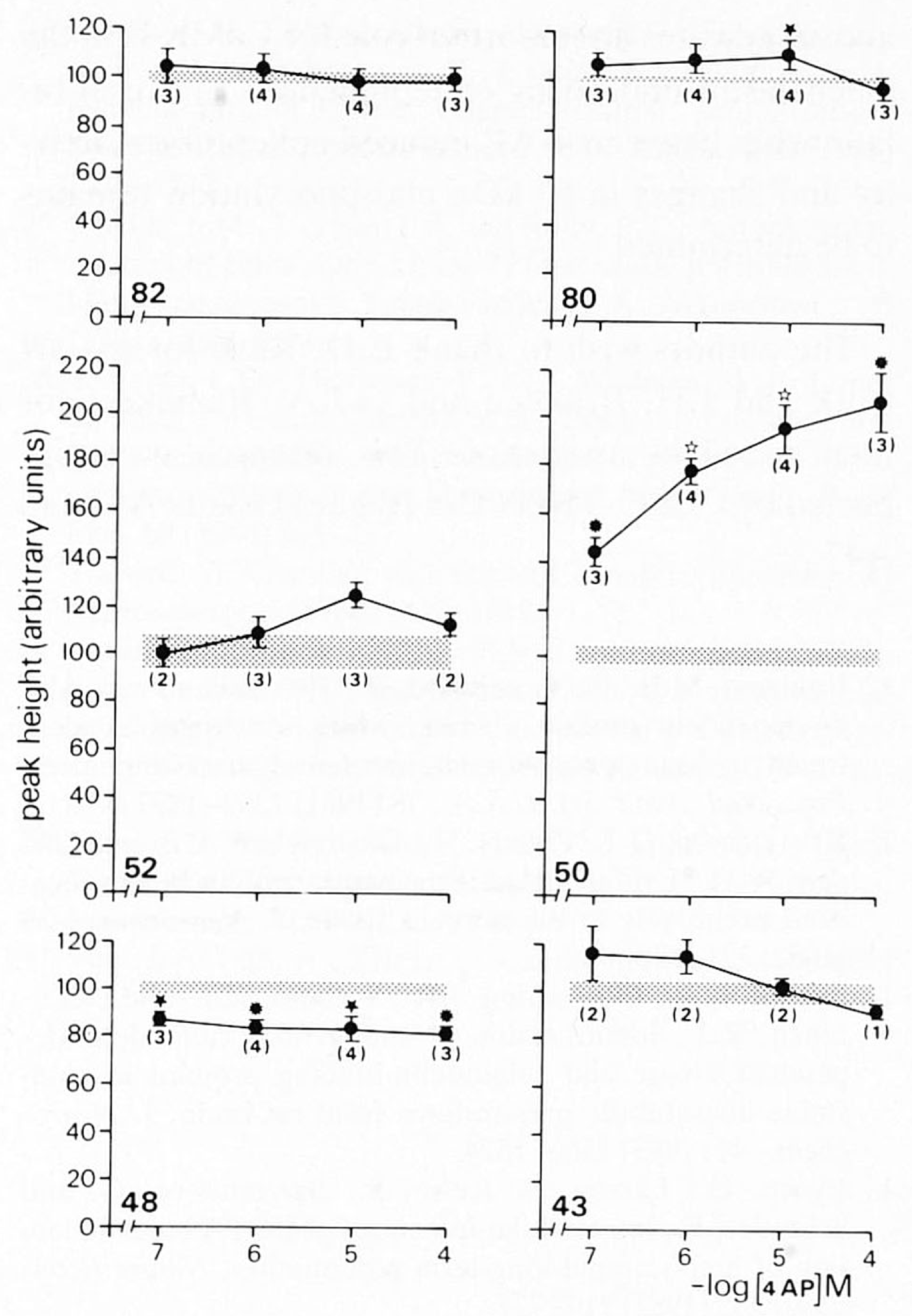

Fig. 3. Dose-dependency of the 4-AP effect on the phosphorylation of the 6 phosphoproteins indicated in Fig. 1. Quantification was performed as described in the legend of Fig. 2. Indicated are: the numbers in parentheses are the no. of determinations per concentration, the standard error of the mean (S.E.M., bars), the S.E.M. of the controls (shaded area) and the level of significance as determined by Student's $t$-test $(\star$, $2 P<0.05,{ }^{*}, 2 P<0.01$, 放, $\left.2 P<0.005\right)$.

on the phosphorylation of the $48 \mathrm{kDa}$ protein was variable, no effect was seen in the experiments shown in Fig. 2, whereas a small but significant inhibition of phosphorylation is shown in Fig. 3. The phosphorylation of the $80 \mathrm{kDa}$ protein was only significantly stimulated at $10^{-5} \mathrm{M} 4$-AP (Figs. 2, 3). No effect could be detected on the phosphorylation of the other major phosphoproteins (82, 52 and $43 \mathrm{kDa})$ at any of the 4-AP concentrations tested. The stimulation of the $50 \mathrm{kDa}$ protein phosphorylation could already be observed after a 5 -min 4 -AP treatment (data not shown).

The effects of 4-AP on protein phosphorylation were not observed after incubation of the $\mathrm{P}_{2}$ fraction with $10^{-7}$ to $10^{-4} \mathrm{M} 4$-AP in vitro. Incubation of the $\mathrm{P}_{2}$ fraction with $1 \mathrm{mM} 4$-AP resulted in a $40 \%$ decrease of $50 \mathrm{kDa}$ phosphorylation (results not shown). Thus, stimulation of phosphorylation of the $50 \mathrm{kDa}$ protein is probably not the consequence of a direct effect of 4-AP on the $50 \mathrm{kDa}$ protein phosphorylation system.

The phosphorylation of the $50 \mathrm{kDa}$ protein in the hippocampal $\mathrm{P}_{2}$ fraction has been shown to be strongly $\mathrm{Ca}^{2+} /$ calmodulin-dependent ${ }^{2.26}$. Based on its relative molecular weight, its $\mathrm{Ca}^{2+} /$ calmodulin sensitivity and its subcellular distribution ${ }^{26}$, the 4-AP-sensitive phosphoprotein is most probably the $\alpha$ or $Q$ subunit of brain $\mathrm{Ca}^{2+} /$ calmodulin sensitive protein kinase type II (CaMK II $)^{4.12}$.

In another experimental model for epilepsy, the septal kindling model, a reduction of phosphate incorporation into a $50 \mathrm{kDa}$ protein in hippocampal synaptosomal plasma membranes was observed ${ }^{33}$. The phosphorylation of this protein and the effect of kindling were calmodulin dependent ${ }^{34}$. Biochemical characterization showed that the protein is most likely the $\alpha$ or $Q$ subunit of the CaMK II ${ }^{8}$. This protein kinase is a predominant brain phosphoprotein ${ }^{4.10}$, consisting of two subunits. CaMK II has a number of substrate proteins in brain, such as cytoskeletal elements (tubulin and microtubule-associated protein$2)^{7.14 .24 .35}$ and synapsin $I^{12}$. The activity of the kinase towards synapsin I is stimulated by autophosphorylation $^{25}$. The phosphorylation of synapsin I by CaMK II probably leads to the dissociation of synapsin I from synaptic vesicles, resulting in an enhancement of synaptic transmission ${ }^{17}$, as elegantly shown in the squid giant axon after pressure injection of the kinase, thereby confirming the hypothesis that the phosphorylation of synapsin I by CaMK II may regulate vesicle function in presynaptic terminals ${ }^{21}$.

In the mollusc, Hermissenda, incubation of the eyes and ganglia with ${ }^{32} \mathrm{P}_{\mathrm{i}}$ in the presence of 4 -AP resulted in a more than $85 \%$ reduction of phosphate incorporation into a $25 \mathrm{kD}$ a protein ${ }^{19}$. This effect was found at a concentration range and time course similar to those required to block $\mathrm{I}_{\mathrm{A}}$ in molluscan neurons $^{20}$. This $25 \mathrm{kDa}$ protein was found to be a substrate for cAMP- and $\mathrm{Ca}^{2+}$-dependent protein kinase ${ }^{20} . \mathrm{K}^{+}$depolarization of Hermissenda neurons, which increases $\mathrm{Ca}^{2+}$ uptake and inactivates voltagedependent $\mathrm{K}^{+}$currents, also reduces the phosphorylation of the $25 \mathrm{kDa}$ protein ${ }^{19}$. Injection of rat brain 
CaMK II into giant axons reduces $\mathrm{I}_{\mathrm{A}}$ and $\mathrm{I}_{\mathrm{C}}$ in Hermissend $a^{1}$. From the combination of biochemical and biophysical data Neary and coworkers concluded that $\mathrm{Ca}^{2+}$-stimulated protein phosphorylation can alter the activity of $\mathrm{K}^{+}$currents in molluscan neurons $^{20}$.

In our hippocampal slice studies, the dose- and time-dependency of the 4-AP effect on $50 \mathrm{kDa}$ phosphorylation closely resemble those reported for 4AP-induced epileptiform activity in this system ${ }^{5,11,30,31}$. Although the evidence summarized

1 Acosta-Urquidi, J., Neary, J.T., Goldenring, J.R., Alkon, D.L. and DeLorenzo, R.J., Modulation of $\mathrm{I}_{\mathrm{Ca}}$ and late $\mathrm{K}$ currents by intrasomatic injection of Ca-calmodulin-dependent protein kinase in Hermissenda giant neurons, Soc. Neurosci. Abstr., 10 (1984) 1129.

2 Bär, P.R., Tielen, A.M., Lopes da Silva, F.H., Zwiers, H. and Gispen, W.H., Membrane phosphoproteins of rat hippocampus: sensitivity to tetanic stimulation and enkephalin, Brain Research, 245 (1982) 69-79.

3 Baranyi, A. and Feher, O., Convulsive effects of 3-aminopyridine on cortical neurons, Electroencephalogr. Clin. Neurophysiol., 47 (1979) 745-751.

4 Bennett, M.K., Erondu, N.E. and Kennedy, M.B., Purification and characterization of a calmodulin-dependent protein kinase that is highly concentrated in brain, J. Biol. Chem., 258 (1983) 12735-12744.

5 Buckle, P.J. and Haas, H.L., Enhancement of synaptic transmission by 4 -aminopyridine in hippocampal slices of the rat, J. Physiol. (London), 326 (1982) 109-122.

6 De Graan, P.N.E., Lopes da Silva, F.H. and Gispen, W.H., The role of hippocampal phosphoproteins in longterm potentiation. In R.L. Isaacson and K.H. Pribram (Eds.), The Hippocampus, Vol. 3, Plenum Press, New York, 1986, pp. 187-216.

7 Goldenring, J.R., Casanova, J.E. and DeLorenzo, R.J., Tubulin-associated calmodulin-dependent protein kinase: evidence for an endogenous complex of tubulin with a calcium-calmodulin-dependent kinase, J. Neurochem., 43 (1984) 1669-1679.

8 Goldenring, J.R., Wasterlain, C.G., Oestreicher, A.B., De Graan, P.N.E., Farber, D.B., Glaser, G. and DeLorenzo, R.J., Kindling induces a long-lasting change in the activity of a hippocampal membrane calmodulin-dependent protein kinase system, Brain Research, 377 (1986) $47-53$.

9 Griffiths, T., Evans, M.C. and Meldrum, B.S., Intracellular sites of early calcium accumulation in the rat hippocampus during status epilepticus, Neurosci. Lett., 30 (1982) 329-344.

10 Griffiths, T., Evans, M.C. and Meldrum, B.S., The role of calcium in selective neuronal loss in status epilepticus: an experimental study in the rat hippocampus. In A. BaldyMoulines, D.A. Ingvar and B.S. Meldrum (Eds.), Current Problems in Epilepsy, Libbey, London, 1983, pp. 285-291.

11 Haas, H.L., Wieser, H.G. and Yasargil, M.G., 4-Aminopyridine and fiber potentials in rat and human hippocampal slices, Experientia, 39 (1983) 114-115. above indicates an important role for CaMK II in the mechanisms underlying epileptogenesis, a causal relationship between 4-AP-induced epileptiform activity and changes in $50 \mathrm{kDa}$ phosphorylation remains to be determined.

The authors wish to thank E.D. Kluis for the art work and J.H. Brakkee and G.J.A. Ramakers for their excellent assistance. This research was supported by CLEO-TNO (The Hague) Grants A42 and A47.

12 Kennedy, M.B. and Greengard, P., Two calcium/calmodulin-dependent protein kinases, which are highly concentrated in brain phosphorylate protein I at distinct sites, Proc. Natl. Acad. Sci. U.S.A., 78 (1981) 1293-1297.

13 Kristjansson, G.I., Zwiers, H., Oestreicher, A.B. and Gispen, W.H., Evidence that the synaptic protein B-50 is localized exclusively in the nervous tissue, J. Neurochem., 39 (1982) 371-378.

14 Larson, R.E., Goldenring, J.R., Vallano, M.L. and DeLorenzo, R.J., Identification of endogenous calmodulin-dependent kinase and calmodulin-binding proteins in coldstable microtubule preparations from rat brain, J. Neurochem., 44 (1985) 1566-1574.

15 Lynch, G., Larson, J., Kelso, S., Barrionuevo, G. and Schottler, F., Intracellular injections of EGTA block induction of hippocampal long-term potentiation, Nature (London), 305 (1983) 719-721.

16 Llinás, R., Walton, K. and Bohr, V., Synaptic transmission in squid giant synapse after potassium conductance blockage with external 3- and 4-aminopyridine, Biophys. J., 16 (1976) 83-86.

17 Llinás, R., McGuinness, T.L., Leonard, C.S., Sugimori, M. and Greengard, P., Intraterminal injection of synapsin I or calcium/calmodulin-dependent protein kinase II alters neurotransmitter release at the squid giant synapse, Proc. Natl. Acad. Sci. U.S.A., 82 (1985) 3035-3039.

18 Lowry, O.H., Rosebrough, N.J., Farr, A.L. and Randall, R.J., Protein measurement with the Folin phenol reagent, J. Biol. Chem., 193 (1951) 265-275.

19 Neary, J.T. and Alkon, D.L., Protein phosphorylation/dephosphorylation and the transient, voltage-dependent potassium conductance in Hermissenda crassicornis, J. Biol. Chem., 258 (1983) 8979-8983.

20 Neary, J.T., Modulation of ion channels by $\mathrm{Ca}^{2+}$-activated protein phosphorylation: a biochemical mechanism for associative learning, Prog. Brain Res., 69 (1986) 91-105.

21 Nestler, E.J., Walaas, S.I. and Greengard, P., Neuronal phosphoproteins. Physiological and clinical implications, Science, 225 (1984) 1357-1364.

22 Nicholson, C., Steinberg, R., Stockle, H. and Ten Bruggecate, G., Calcium decrease associated with 4-aminopyridine-induced potassium increase in cat cerebellum, Neurosci. Lett., 3 (1976) 315-319.

23 Routtenberg, R. and Lovinger, D.M., Selective increase in phosphorylation of a $47 \mathrm{kDa}$ protein (F1) directly related to long-term potentiation, Behav. Neural. Biol., 43 (1985) $3-11$. 
24 Sahyoun, N., LeVine, III, H., Bronson, D., Siegel-Greenstein, F. and Cuatrecasas, P., Cytoskeletal calmodulin-dependent protein kinase. Characterization, solubilization, and purification from rat brain, J. Biol. Chem., 260 (1985) $1230-1237$

25 Shields, S.M., Vernon, P.J. and Kelly, P.T., Autophosphorylation of calmodulin-kinase II in synaptic junctions modulates endogenous kinase activity, J. Neurochem., 43 (1984) 1599-1609.

26 Schrama, L.H., De Graan, P.N.E., Wadman, W.J., Lopes da Silva, F.H. and Gispen, W.H., Long-term potentiation and 4-aminopyridine-induced changes in protein- and lipid phosphorylation in the hippocampal slice, Prog. Brain Res., 69 (1986) 245-257.

27 Thesleff, S., Aminopyridines and synaptic transmission, Neuroscience, 5 (1980) 1413-1419.

28 Tielen, A.M., De Graan, P.N.E., Mollevanger, W.J., Lopes da Silva, F.H. and Gispen, W.H., Quantitative relationship between post-tetanic biochemical and electrophysiological changes in brain slices, Brain Research, 277 (1983) 189-192.

29 Turner, R.W., Baimbridge, K.G. and Miller, J.J., Calcium-induced long-term potentiation in the hippocampus, Neuroscience, 7 (1982) 1411-1416.

30 Van Harreveld, A., Effects of 4-aminopyridine on the field potentials of hippocampal slices, Neurosci. Lett., 50 (1984) 283-287.

31 Voskuyl, R.A. and Albus, H., Spontaneous epileptiform discharges in hippocampal slices induced by 4-aminopyridine, Brain Research, 342 (1985) 54-66.

32 Wadman, W.J., Heinemann, U., Konnerth, A. and Neuhaus, S., Hippocampal slices of kindled rats reveal calcium involvement in epileptogenesis, Exp. Brain Res., 57 (1985) 404-407.

33 Wasterlain, C.G. and Farber, D.B., A lasting change in protein phosphorylation associated with septal kindling, Brain Research, 247 (1982) 191-194.

34 Wasterlain, C.G. and Farber, D.B., Kindling alters the calcium/calmodulin-dependent phosphorylation of synaptic plasma membrane proteins in hippocampus, Proc. Natl. Acad. Sci. U.S.A., 81 (1984) 1253-1257.

35 Yamamoto, H., Fukanaga, K., Goto, S., Tanaka, E. and Miyamoto, E., $\mathrm{Ca}^{2+}$, calmodulin-dependent regulation of microtubule formation via phosphorylation of microtubuleassociated protein 2, $\tau$ factor, and tubulin, and comparison with the cyclic AMP-dependent phosphorylation, J. Neurochem., 44 (1985) 759-768.

36 Zwiers, H. Veldhuis, H.D., Schotman, P. and Gispen, W.H., ACTH, cyclic nucleotides, and brain protein phosphorylation in vitro, Neurochem. Res., 1 (1976) 669-677. 